\title{
The impact of anthropogenic factors on the occurrence of molybdenum in stream and river sediments of central Upper Silesia (Southern Poland)
}

\author{
Wpływ czynników antropogenicznych na występowanie \\ molibdenu w osadach strumieniowych i rzecznych \\ w centralnej części Górnego Śląska (południowa Polska)
}

\begin{abstract}
${ }^{*}$ Dr hab. prof. nadzw. PIG-PIB Anna Pasieczna, prof. dr hab. Izabela Bojakowska - Polish Geological Institute - National Research Institute, Rakowiecka 4, 00-975 Warsaw, e-mail: anna.pasieczna@pgi.gov.pl,

${ }^{* *}$ mgr Weronika Nadłonek, Departament of Economic Geology, Faculty of Earth Sciences, University of Silesia, Będzińska 60, 41-200, Sosnowiec, Poland
\end{abstract} izabela.bojakowska@pgi.gov.pl,

Keywords: molybdenum, stream and river sediments, anthropogenic pollution, Upper Silesia-Southern Poland Słowa kluczowe: molibden, osady rzeczne i strumieniowe, zanieczyszczenia antropogeniczne, Górny Śląsk-południowa Polska

\begin{abstract}
In our study, a detailed survey was conducted with the aim to determine the distribution and possible anthropogenic sources of molybdenum in river and stream sediments in the central Upper Silesian Industrial Region (Southern Poland), where for many years, iron and zinc smelters as well as coking and thermal power plants were operating. At the same time, this has also been a residential area with the highest population density in the country. Sediments (1397 samples in total) were collected from rivers and streams, and analysed for the content of molybdenum and 22 other elements. ICP-AES and CV-AAS methods were applied for the determination of the content of elements. The studies revealed molybdenum content in the range of $<0.5-$ $204.8 \mathrm{mg} \cdot \mathrm{kg}-1$ with the average content $1.9 \mathrm{mg} \cdot \mathrm{kg}-1$. About half of the samples contained $<0.5 \mathrm{mg} \cdot \mathrm{kg}-1$ of molybdenum, and only $4.6 \%$ of the samples showed values $>5 \mathrm{mg} \cdot \mathrm{kg}-1$. The spatial distribution of molybdenum demonstrated by the geochemical map has indicated that the principal factor determining its content in sediments is the discharge of wastewater from steelworks and their slag heaps. Another source of this element in sediments has been the waste of the historical mining of zinc ore and metallurgy of this metal. Additionally, molybdenum migration from landfills of power plants, coal combustion and Mo emission to the atmosphere and dust fall-out have been significant inputs of Mo pollution to the sediments.
\end{abstract}

(c) IOŚ-PIB

\section{INTRODUCTION}

In the context of environmental distributions of molybdenum, a large literature exists on this element in oceanic systems and its role in the functioning of living organisms. Rather less attention has been paid to the distribution of Mo in freshwater systems considering the anthropogenic pollution. In Poland, the determination of its content in stream sediments was conducted during the development of the Geochemical Atlas of Europe [Salminen ed. 2005, De Vos and Tarvainen 2006] and the

\section{Streszczenie}

Opracowanie przedstawia szczegółowe badania zawartości molibdenu w osadach rzek i strumieni w Górnośląskim Okręgu Przemysłowym (południowa Polska), których celem było określenie jego zawartości i możliwych źródeł zanieczyszczeń antropogenicznych. Jest to region gdzie przez wiele lat działały huty cynku, a obecnie-hutyżelaza, koksownie ielektrociepłownie. Jednocześnie jest to obszar miejski o największej gęstości zaludnienia w kraju. Osady (1397 próbek) pobrano z rzek oraz strumieni i oznaczono w nich zawartość molibdenu i 22 innych pierwiastków. Ich zawartość określono metodami ICP-AES oraz CV-AAS. Badania wykazały zawartość molibdenu w zakresie $<0,5-204,8 \mathrm{mg} \cdot \mathrm{kg}-1$; średnia zawartość wynosi 1,9 mg·kg-1. Około połowa próbek zawiera $<0,5 \mathrm{mg}$ a tylko $4,6 \%$ próbek charakteryzuje się zawartością $>5 \mathrm{mg} \cdot \mathrm{kg}-1$ molibdenu. Rozkład przestrzenny molibdenu przedstawiony kartograficznie wskazuje, że głównym czynnikiem determinującym jego zawartość w osadach jest odprowadzanie ścieków z hut żelaza i oddziaływanie składowisk odpadów pohutniczych. Źródłem tego pierwiastka są również odpady historycznego górnictwa i hutnictwa rud cynku, a kolejnym jego emisja do atmosfery podczas spalania węgla i migracja ze składowisk odpadów elektrowni. geochemical prospecting in the eastern part of the Carpathians [Bojakowska and Borucki 1994].

The main purpose of this work was to identify sources and distribution of molybdenum in river and stream sediments in the central Upper Silesian Industrial Region (Southern Poland), where for many years, iron and zinc smelters as well as coking and thermal power plants were the leading activity. At the same time, this has also been a residential area with the highest 
population density in the country (about 370 people per square kilometre, compared to the national average of 124).

The contamination of stream and river sediments by this potentially toxic element is a serious problem in areas polluted by the ferrous and nonferrous industry, coking plants, combined coal-fired heat and power plants, and industrial waste landfills [Alary et al. 1983, Li and Thornton 2001, Smedley and Kinniburgh 2017]. Various studies have revealed that the concentration of molybdenum in sediments is directly related with the discharge of sewage from industrial plants and atmospheric pollution [Battogtokh et al. 2014, Amorello and Orecchio 2015].

Molybdenum occurs naturally in minerals, rocks and soils as well as in aqueous form. The average content of Mo is given for the upper Earth's crust as $1.1 \mathrm{mg} \cdot \mathrm{kg}-1$, and its concentration is elevated in granitic rocks and argillaceous sediments up to $2.5 \mathrm{mg} \cdot \mathrm{kg}-1$ [Kabata-Pendias and Mukheherjee 2007]. Molecular binding of molybdenum by organic matter causes its accumulation (often with copper) in sedimentary rocks. Its highest concentration is found in kaustobiolites (up to $2 \%$ ) and bituminous shale (up to $200 \mathrm{mg} \cdot \mathrm{kg}-1$ ), as well as in copper-bearing shale and ironmanganese concretions [Enzmann 1972, Migaszewski and Gałuszka 2003, Salminen 2005, Dubinin et al. 2008].

Mo exists in several oxidation states; $+4,+5$ and +6 are the most important for environment [Smedley and Kinniburgh 2017]. Molybdenum easily forms complex anionic compounds that are mobile under neutral and alkaline conditions [Borovec 1993, Sjöstedt et al. 2009]. In acidic environments, it is bound by organic matter, absorbed by iron, aluminium and manganese hydroxides, and co-precipitated with cations (Pb2+, $\mathrm{Cu} 2+, \mathrm{Zn} 2+$, $\mathrm{Mn2+}$, Ca2+) [Kabata-Pendias and Pendias, 1999, De Vos and Tarvainen 2006, Poulson et al. 2009, Fu et al. 2013].

In river and stream sediments, molybdenum, like other metals, accumulates particularly easily in their fine-grained fraction [Chen et al. 2012, Tang et al. 2014]. It can accumulate to a dangerous level in the trophic chain, especially in predators, posing a risk to humans and animals eating fish or molluscs from contaminated sites [De Gale et al. 2004; Vink 2009, Fu et al. 2013, Xiao et al. 2013].

Molybdenum is an essential trace element for plant, animal and human health, however, the requirement for it is relatively low [Kabata-Pendias and Mukheherjee 2007]. High molybdenum concentrations in environmental matrices (from natural sources or through pollution) may result in poisoning. Molybdenum is a component of large number of enzymes, which catalyse chemical reactions involved in cycling of N, C and S [Mendel and Bittner 2006, Kabata-Pendias and Mukheherjee 2007, Schwarz et al. 2009]. The toxic effect of molybdenum on living organisms depends on its chemical form and animal species [Vyskočil and Viau 1999, Halmi et al. 2014]. In humans and animals, excessive molybdenum levels can lead to bone deformation and disruption of metabolic processes [Migaszewski and Gałuszka 2016].

The main source of anthropogenic pollution of river and stream sediments by molybdenum is extraction and processing of its ore [Yu et al. 2008, Yu et al. 2011]. Sediment contamination with molybdenum is also due to its application in many industrial processes, its content in fertilizers, fuel combustion, wastewater discharges, and the disposal of some waste types, such as those of power plants. Because of its resistance to high temperature, molybdenum is added to lubricants, high-speed steel cutting tools, corrosion-resistant steels, and special alloys. It is also used as a fireproof coating for other metals. Molybdenum compounds are applied as catalysts in the petroleum industry, and as dyes for the production of paints, inks, plastics and rubber products [Reimann and De Caritat 1998, Smedley and Kinniburgh 2017]. The molybdenum content in stream sediments of Europe usually does not exceed $0.41 \mathrm{mg} \cdot \mathrm{kg}-1$ (median $0.6 \mathrm{mg} \cdot \mathrm{kg}-1$ ). Anomalous concentrations (up to $117 \mathrm{mg} \cdot \mathrm{kg}-1$ ) have been found in northern and central Sweden in areas of sulphide mineralization in granites and schists [Salminen ed. 2005, De Vos and Tarvainen 2006]. The accumulation of molybdenum (up to $12.2 \mathrm{mg} \cdot \mathrm{kg}-1$ ) in the Elbe River sediments is considered to have originated from natural (weathering of pegmatites) and anthropogenic (coal combustion from the Bohemian lignite basin) sources [Borovec 1993].

The stream sediments of Poland contain $0.17-1.94 \mathrm{mg} \cdot \mathrm{kg}-1$ of molybdenum and the median is $0.42 \mathrm{mg} \cdot \mathrm{kg}-1$; while in lake sediments, the median is $1.1 \mathrm{mg} \cdot \mathrm{kg}-1$ [Salminen ed. 2005, De Vos and Tarvainen 2006]. Higher abundance of molybdenum is observed in stream sediments of the Bieszczady Mountains, where the average is $1.2 \mathrm{mg} \cdot \mathrm{kg}-1$, and in the area of menilite shale (which itself contains up to $144 \mathrm{mg} \cdot \mathrm{kg}-1$ of Mo) - up to $22.1 \mathrm{mg} \cdot \mathrm{kg}-1$ [Gucwa and Wieser 1980, Bojakowska and Borucki 1994, Stojek, 2013].

\section{MATERIALS AND METHODS}

\subsection{Study area}

In administrative terms, the study area belongs to the central part of the Silesian Voivodeship. It is located within the Katowice Upland, which is the central part of the Silesian Upland [Kondracki 2009]. Geologically, the area is composed of Carboniferous, Triassic, Neogene and Quaternary deposits. The last ones are represented mainly by glacial tills [Wyczółkowski 1957, Machowski 2010]. Of historical importance are zinc and lead ores in Triassic ore-bearing dolomites, which were among the largest and richest $\mathrm{Zn}-\mathrm{Pb}$ ore deposits in the world [Szuwarzyński 1996, Paulo and StrzelskaSmakowska 2000]. Most of the study area has been significantly transformed as a result of mining and energy, metallurgical and chemical industries [Mucha 2010, Cempiel et al. 2014]. The effects of pollution are visible on geochemical maps in the form of geological and anthropogenic anomalies of many elements in soils and sediments of streams, rivers and lakes [Pasieczna 2016a, b, c, d, Pasieczna and Bojakowska 2016]. For many years, the most important sectors in the investigated area have been coal mining and iron metallurgy, as well as zinc metallurgy in the past. The largest environmental changes have been caused by hard coal mining (Sośnica-Makoszowy, Budryk, Bielszowice, Pokój, Halemba-Wirek and Wujek mines) and the historical and present-day iron metallurgy (respectively: Antonienhütte, Bertha, Donnersmarck, Hubertus, Ida, Eintracht, Bethlen-Falwa, and Zabrze, Pokój, Silesia, Zygmunt, Kościuszko, Batory, Florian and Baildon) [Degenhardt 1870, Sulimierski and Walewski 1880-1914, Niemierowski 1983, Szulc 2013]. The early processes of iron melting were based on local raw materials 


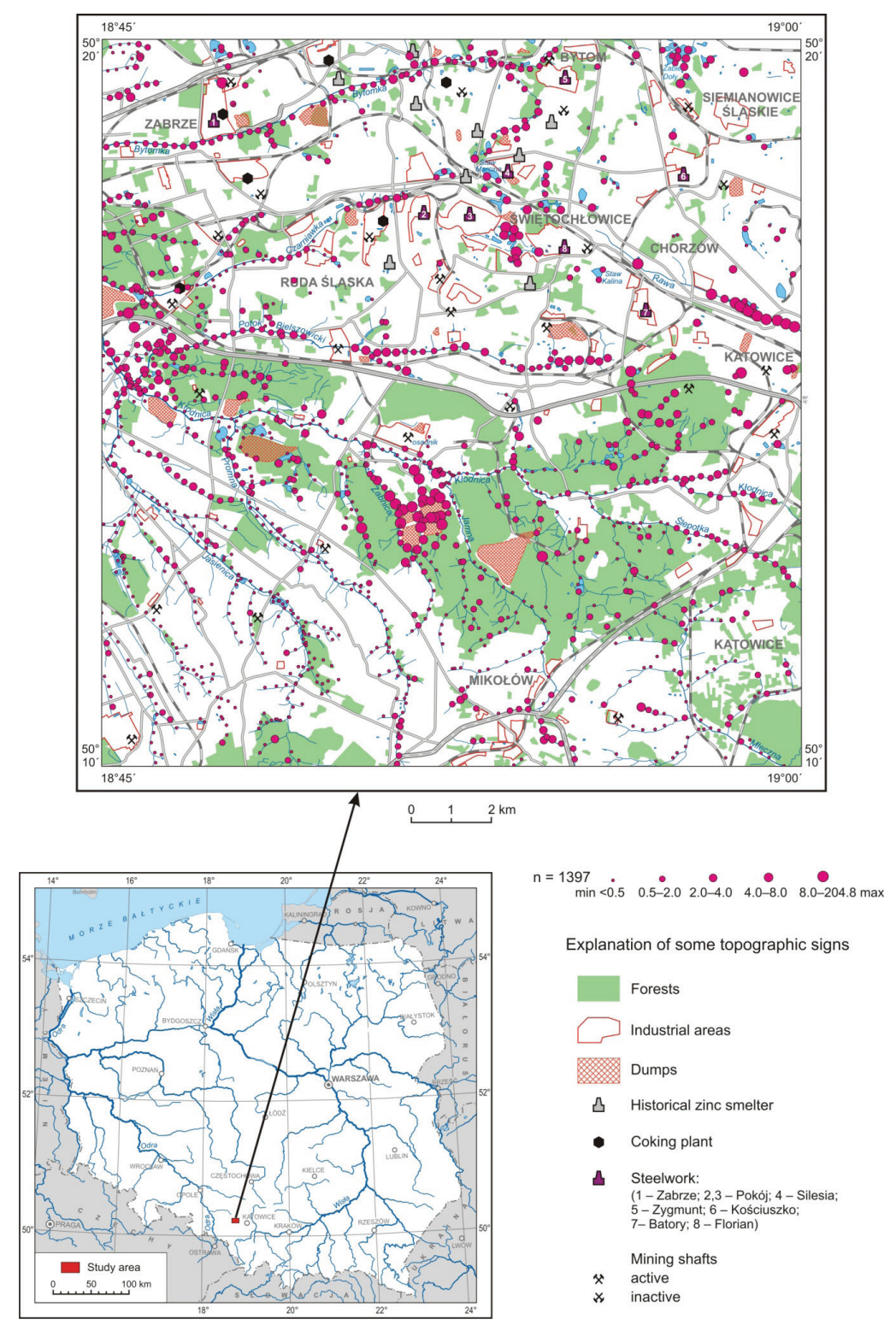

Figure 1. Molybdenum content in sediments $(\mathrm{mg} \cdot \mathrm{kg}-1)$.

(small deposits of turf ores). Currently, pig iron is produced from imported iron ore, mainly from Norway and Germany, and from steel scrap [Burchart-Karol 2010, Maj et al. 2010; Pater 2014]. Moreover, heaps of iron-smelting waste are located near the steelworks and smelters. These are predominantly slag and, in a smaller amount, moulding sand, refractory debris, sludge and post-treatment sediments. The slag is used as road aggregate [Sordoń-Kulibaba 2010].

In the Upper Silesian Industrial Region, an important source of environmental pollution by metals has been the historical $\mathrm{Zn}-\mathrm{Pb}$ ore mining and zinc smelting. In the past, there were several zinc smelters using local ore deposits: Carlshütte, Godullahütte, Hugo, Franciszek, Liebe-Hoffnung, Rozamunda, Gute Hoffnung, Morgenroth, Marien Wunsch, Bobrek, Dawid, Konstancja, Gabor, Victor, Guidotto, Klara and Silesia [Degenhardt 1870, Sulimierski and Walewski 1880-1914, Molenda 1963, 1972, Cygorijni 1989, Dworak, 1995].
Power and coking plants are the source of dust carrying heavy metals. The Jadwiga coking plant, which is among the largest coke producers in Poland, is located in Zabrze. The plant has been operating under different names since 1884. Other coking plants active in different periods are Makoszowy, Walenty, Zaborze, Concordia and Orzegów.

The study area is characterized by an unvaried landscape, generally descending towards the west. The land relief is enriched with anthropogenic transformation features represented by water-filled depressions, which developed due to the mining activities, and with over-level heaps and dumps on which mining and industrial waste is deposited. Northern part of the analysed area is dominated by urban and industrial areas, and the southern - by forests and farmland (Fig. 1). The western part of the area belongs to the drainage basin of the Kłodnica River that flows into the Odra River. The right-bank tributaries of the Kłodnica River are the Bytomka River, Czarniawka River and Potok Bielszowicki 
Table 1. Land use and sources of sediment pollution.

\begin{tabular}{|c|c|c|c|}
\hline River/Stream & Land use & Main source of pollution & Channel \\
\hline Bytomka River & urban and industrial & $\begin{array}{l}\text { industrial and municipal sewage, mine } \\
\text { water }\end{array}$ & engineered \\
\hline Czarniawka River & urban and industrial & $\begin{array}{l}\text { industrial and municipal sewage, mine } \\
\text { water }\end{array}$ & engineered \\
\hline Jamna Stream & $\begin{array}{l}\text { forest, peatland, agricultural, } \\
\text { urban }\end{array}$ & $\begin{array}{l}\text { surface runoff, fertilizers, municipal } \\
\text { sewage }\end{array}$ & natural \\
\hline Jasienica Stream & agricultural, wetland & surface runoff, fertilizers & natural \\
\hline Kłodnica River & urban, industrial, forest & $\begin{array}{l}\text { industrial and municipal sewage, mine } \\
\text { water }\end{array}$ & engineered \\
\hline Mleczna River & urban, industrial, forest & $\begin{array}{l}\text { industrial and municipal sewage, mine } \\
\text { water }\end{array}$ & partly engineered \\
\hline $\begin{array}{l}\text { Potok Bielszowicki } \\
\text { Stream }\end{array}$ & urban, industrial, forest & $\begin{array}{l}\text { industrial and municipal sewage, mine } \\
\text { water }\end{array}$ & engineered \\
\hline Promna Stream & agricultural, forest & surface runoff, fertilizers & natural \\
\hline Rawa River & urban and industrial & $\begin{array}{l}\text { industrial and municipal sewage, mine } \\
\text { water }\end{array}$ & engineered \\
\hline Ślepotka Stream & urban, forest & municipal sewage & partly engineered \\
\hline Żabnica Stream & forest & industrial sewage & partly engineered \\
\hline
\end{tabular}

Stream, and the left tributaries include the Promna Stream, Jasienica Stream, Jamna Stream and Ślepotka Stream. Through sewage discharges and the tributaries mentioned above, the Kłodnica River carries contaminants from the western part of the Upper Silesian Industrial Region [Czaja 1999, Nocoń 2009; Nocoń and Kostecki 2005, Nocoń et al. 2006]. The south-eastern area is included in the drainage basin of the Vistula River that is fed by the Mleczna and Rawa rivers. Most of the watercourses channels are regulated and the sources of pollution of sediments are different in the north and south of the analysed area (Table 1).

\section{2. Sampling and methods}

Sediments (1397 samples in total) were collected from rivers, streams, ditches and canals, and stagnant water bodies (lakes, settling tanks, and ponds). The sediment samples, weighing ca. $500 \mathrm{~g}$ (fined-grained if possible), were taken from the shores of water reservoirs and watercourses. The distance between sampling sites along watercourses was about $250 \mathrm{~m}$. Sediment samples were air-dried and then sieved through the nylon sieve to a grain size $<0.2 \mathrm{~mm}$. Sample digestion was carried out in aqua regia, and the content of Mo (and other elements) was determined by the inductively coupled plasma atomic emission spectrometry (ICP-AES) method. Determination of $\mathrm{Hg}$ was performed using the cold vapour-atomic absorption (CV-AAS) method. The quality control of the determinations was performed through employing reference materials with certified content of elements studied $(2 \%$ of all samples), analysis of duplicate samples ( $5 \%$ of all samples) and laboratory control samples ( $5 \%$ of all samples). The purity of reagents and vessels, as well as sample digestion step were monitored using the reagent blank samples and procedural blank samples. The expanded uncertainty of the obtained results (with the assumed probability level of $95 \%$ and coverage factor $k=2$ ) did not exceed $25 \%$.

\subsection{Geochemical mapping and statistical analysis}

The obtained results of the molybdenum content in sediments are shown on the map in the form of circular diagrams, assigning their respective diameters to individual classes of contents arranged in geometric progression (Fig. 1).

Calculations of statistical parameters were performed for the whole set of results and for the distinguished subsets (Table 2).

The subsets were established for areas of the individual drainage basins, sediment types (clayey, silty, sandy, organic), land use types (arable fields, barren lands, forests, gardens, lawns, meadows, parks), and water body types (canal/ditch, lake/pond, river/stream). If the molybdenum concentration was below the method detection limit $(<0.5 \mathrm{mg} \cdot \mathrm{kg}-1)$, a half of the value of detection limit was used for statistical calculations. Principal Component Analysis (PCA) was used to group sources (anthropogenic, lithogenic or mixed) contributing to observed pollution (Table 3 ). Only samples with molybdenum content $>0.5 \mathrm{mg} \cdot \mathrm{kg}-1$ were selected for PCA.

\section{RESULTS AND DISSCUSION}

The molybdenum content in the analysed sediments varied in the range of $<0.5-204.8 \mathrm{mg} \cdot \mathrm{kg}-1$. The average content and geometric mean were $1.9 \mathrm{mg} \cdot \mathrm{kg}-1$ and $0.7 \mathrm{mg} \cdot \mathrm{kg}-1$, respectively (Table 2). Almost half of the samples contained less than $0.5 \mathrm{mg} \cdot \mathrm{kg}-1$ of molybdenum and $37 \%$ of sediments showed the content of 
Table 2. Statistical parameters of molybdenum content ( $\mathrm{mg} \cdot \mathrm{kg}-1)$.

\begin{tabular}{|c|c|c|c|c|c|}
\hline \multicolumn{2}{|r|}{ Sediments } & \multirow{2}{*}{$\begin{array}{c}\begin{array}{c}\text { Number of } \\
\text { samples }\end{array} \\
1397\end{array}$} & \multirow{2}{*}{$\begin{array}{c}\text { Range } \\
<0.5-204.8\end{array}$} & \multirow{2}{*}{$\begin{array}{c}\text { Mean } \\
1.9\end{array}$} & \multirow{2}{*}{$\begin{array}{c}\text { Geom. mean } \\
0.7\end{array}$} \\
\hline All samples & & & & & \\
\hline Sediment type & $\begin{array}{l}\text { Clay } \\
\text { Silty } \\
\text { Sandy } \\
\text { Organic }\end{array}$ & $\begin{array}{c}50 \\
182 \\
958 \\
207\end{array}$ & $\begin{array}{l}<0.5-8.4 \\
<0.5-200.0 \\
<0.5-204.8 \\
<0.5-108.5\end{array}$ & $\begin{array}{l}0.8 \\
2.2 \\
1.7 \\
2.7\end{array}$ & $\begin{array}{l}0.5 \\
0.7 \\
0.6 \\
1.3\end{array}$ \\
\hline Water body type & $\begin{array}{l}\text { Canal/ditch } \\
\text { Lake/pond } \\
\text { River/stream }\end{array}$ & $\begin{array}{l}422 \\
259 \\
691\end{array}$ & $\begin{array}{l}<0.5-204.8 \\
<0.5-115.9 \\
<0.5-48.2\end{array}$ & $\begin{array}{l}2.5 \\
1.9 \\
1.1\end{array}$ & $\begin{array}{l}0.8 \\
0.8 \\
0.5\end{array}$ \\
\hline Drainage basin & $\begin{array}{c}\text { Bytomka River } \\
\text { Czarniawka River } \\
\text { Jamna Stream } \\
\text { Jasienica Stream } \\
\text { Kłodnica River } \\
\text { Mleczna River } \\
\text { Potok Bielszowicki Stream } \\
\text { Promna Stream } \\
\text { Rawa River } \\
\text { Ślepotka Stream } \\
\text { Żabnica Stream }\end{array}$ & $\begin{array}{c}149 \\
59 \\
83 \\
262 \\
325 \\
87 \\
84 \\
107 \\
75 \\
47 \\
55\end{array}$ & $\begin{array}{l}<0.5-12.0 \\
<0.5-6.6 \\
<0.5-2.9 \\
<0.5-2.3 \\
<0.5-204.8 \\
<0.5-5.1 \\
<0.5-8.4 \\
<0.5-1.8 \\
<0.5-200.0 \\
<0.5-3.3 \\
<0.5-26.4\end{array}$ & $\begin{array}{c}1.2 \\
1.0 \\
0.6 \\
<0.5 \\
2.8 \\
0.6 \\
1.4 \\
0.5 \\
10.7 \\
0.6 \\
3.4\end{array}$ & $\begin{array}{c}0.9 \\
0.7 \\
0.5 \\
<0.5 \\
0.8 \\
0.5 \\
1.0 \\
<0.5 \\
2.7 \\
0.5 \\
1.2\end{array}$ \\
\hline Land use & $\begin{array}{l}\text { Arable fields } \\
\text { Barren lands } \\
\text { Gardens } \\
\text { Forests } \\
\text { Lawns } \\
\text { Meadows } \\
\text { Parks }\end{array}$ & $\begin{array}{c}83 \\
480 \\
33 \\
527 \\
38 \\
178 \\
58\end{array}$ & $\begin{aligned} &<0.5-14.2 \\
&< 0.5-200.0 \\
&<0.5-2.3 \\
&< 0.5-204.8 \\
&<0.5-33.0 \\
&<0.5-75.7 \\
&<0.5-115.9\end{aligned}$ & $\begin{array}{l}0.7 \\
2.4 \\
0.9 \\
1.5 \\
2.7 \\
0.9 \\
5.5\end{array}$ & $\begin{array}{c}<0.5 \\
0.9 \\
0.7 \\
0.6 \\
1.1 \\
<0.5 \\
1.1\end{array}$ \\
\hline
\end{tabular}

Table 3. Principal Component Analysis (Varimax-normalized factor model).

\begin{tabular}{|c|c|c|c|}
\hline$\frac{\text { Factors }}{\text { Elements }}$ & $\mathrm{Cr}, \mathrm{Cu}, \stackrel{\mathrm{F} 1}{\stackrel{\mathrm{Fe}}{\mathrm{Mo}}, \mathrm{Ni}, \mathrm{Sn}}$ & $\mathrm{Ag}, \mathrm{As}, \frac{\mathrm{F} 2}{\mathrm{Cd}}, \mathrm{Pb}, \mathrm{Zn}$ & 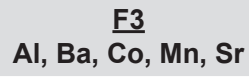 \\
\hline $\mathrm{Ag}$ & 0.092 & 0.841 & -0.003 \\
\hline $\mathrm{Al}$ & 0.046 & 0.107 & 0.522 \\
\hline As & 0.061 & 0.851 & -0.006 \\
\hline $\mathrm{Ba}$ & 0.038 & 0.044 & 0.590 \\
\hline $\mathrm{Ca}$ & 0.421 & 0.248 & 0.379 \\
\hline $\mathrm{Cd}$ & 0.073 & 0.573 & 0.236 \\
\hline Co & -0.016 & -0.040 & 0.807 \\
\hline $\mathrm{Cr}$ & 0.758 & 0.084 & 0.037 \\
\hline $\mathrm{Cu}$ & 0.712 & 0.027 & -0.013 \\
\hline $\mathrm{Fe}$ & 0.626 & 0.127 & 0.193 \\
\hline $\mathrm{Hg}$ & 0.184 & 0.207 & -0.033 \\
\hline $\mathrm{Mg}$ & 0.485 & 0.368 & 0.280 \\
\hline $\mathrm{Mn}$ & -0.031 & -0.002 & 0.859 \\
\hline Mo & 0.634 & -0.066 & 0.005 \\
\hline $\mathrm{Ni}$ & 0.583 & -0.040 & 0.485 \\
\hline $\mathrm{P}$ & 0.252 & 0.036 & 0.217 \\
\hline $\mathrm{Pb}$ & 0.090 & 0.794 & -0.013 \\
\hline$S$ & 0.382 & 0.116 & -0.053 \\
\hline Sn & 0.519 & 0.180 & -0.017 \\
\hline $\mathrm{Sr}$ & 0.331 & 0.141 & 0.584 \\
\hline $\mathrm{Ti}$ & 0.419 & 0.391 & 0.171 \\
\hline V & 0.398 & 0.062 & 0.166 \\
\hline $\mathrm{Zn}$ & 0.104 & 0.827 & 0.128 \\
\hline Variance $\%$ & 23.44 & 11.80 & 9.27 \\
\hline Cumulative \% & & 44.51 & \\
\hline
\end{tabular}



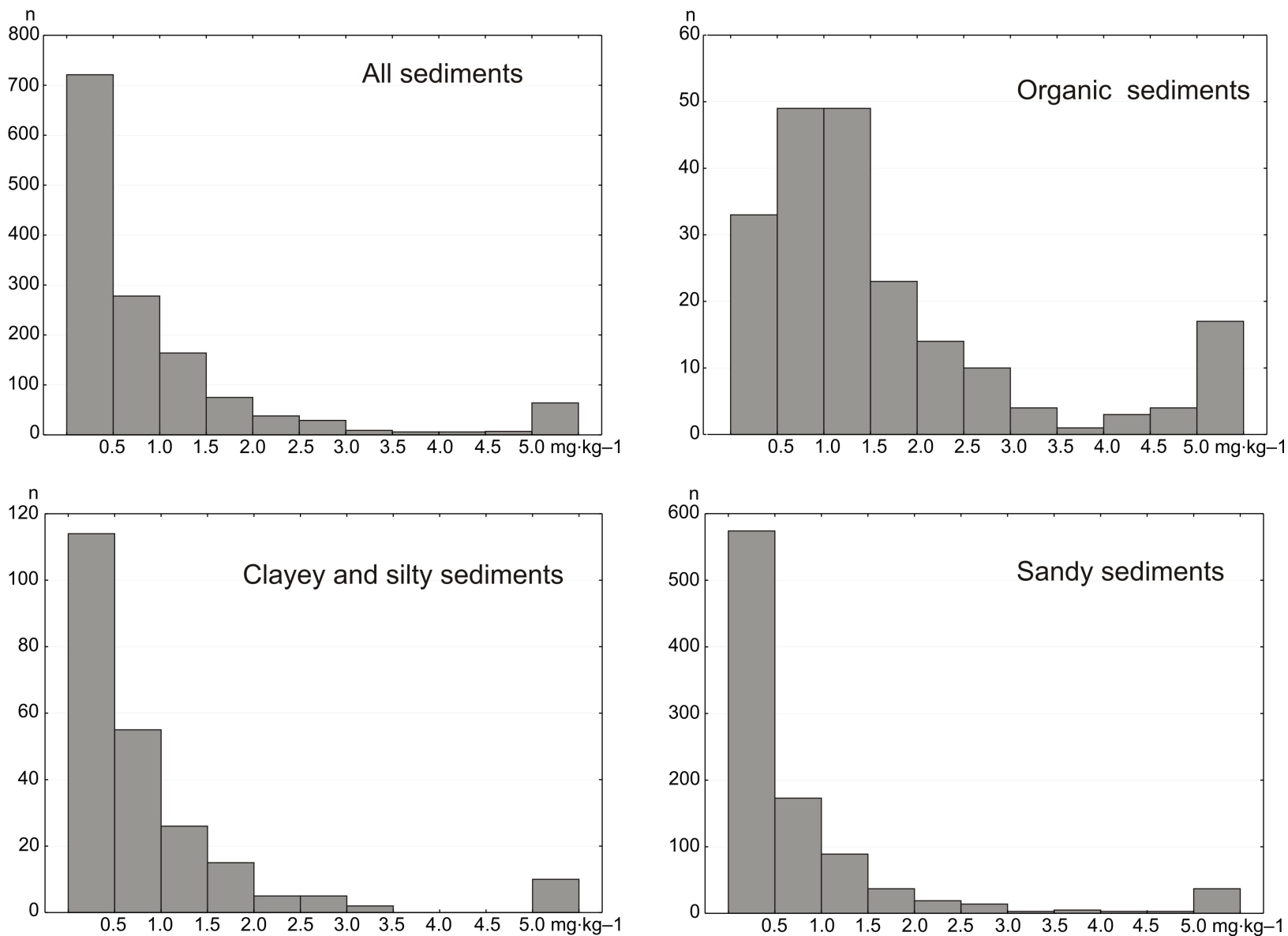

Figure 2. Histograms of molybdenum content in different types of sediments.

$0.5-2 \mathrm{mg} \cdot \mathrm{kg}-1$. The highest concentration $>5 \mathrm{mg} \cdot \mathrm{kg}-1$ was observed in only $4.6 \%$ of the sample population (Fig. 2). Because of the relatively high detection limit of the analytical method used, it was not possible to determine the regional geochemical background of molybdenum. However, we assume that it is similar to the level in stream sediments of Poland $(<0.5 \mathrm{mg} \cdot \mathrm{kg}-1)$ [Salminen 2005, de Vos and Tarvainen 2006].

The variability in molybdenum concentration according to the sediment type was observed in the analysed samples. The highest average content $(2.7 \mathrm{mg} \cdot \mathrm{kg}-1)$ was found in organic, and the lowest in clayey sediments $(0.8 \mathrm{mg} \cdot \mathrm{kg}-1)$ (Table 2). Organic sludge contained usually $0.5-1.5 \mathrm{mg} \cdot \mathrm{kg}-1$ of molybdenum, and sandy and clayey-silty sediments commonly showed $<0.5 \mathrm{mg} \cdot \mathrm{kg}-1$ (Fig. 2).

The greater molybdenum content in organic sludge was presumably due to the accumulation of this element in compounds with organic matter and iron sulphides. This hypothesis is supported by the fact that the content of sulphur and iron in the organic sludge was several times greater than in other sediments (Table 4).

Sediments rich in organic matter commonly showed the presence of mackinawite $(\mathrm{Fe}, \mathrm{Me}) 1+\mathrm{xS})$. This mineral is characterized by considerable adsorption capacity relative to bivalent metals and by the ability of binding, among others, molybdenum [Arakaki and Morse 1993, Morse and Arakaki 1993]. The molybdenum enrichment of organic sludge is also favoured by the conditions
Table 4. Statistical parameters of iron and sulphur content in different types of sediments.

\begin{tabular}{|c|c|c|c|c|}
\hline & \multicolumn{2}{|c}{ Fe \% } & \multicolumn{2}{c|}{ S \% } \\
\hline Sediments & Mean & $\begin{array}{c}\text { Geom. } \\
\text { mean }\end{array}$ & Mean & $\begin{array}{c}\text { Geom. } \\
\text { mean }\end{array}$ \\
\hline All samples $(n=1397)$ & 1.83 & 1.09 & 0.356 & 0.130 \\
\hline Sandy $(n=958)$ & 1.48 & 0.87 & 0.277 & 0.094 \\
\hline Clayey $(n=50)$ & 1.65 & 1.35 & 0.128 & 0.073 \\
\hline Silty $(n=182)$ & 2.11 & 1.48 & 0.320 & 0.170 \\
\hline Organic $(n=207)$ & 3.24 & 2.17 & 0.810 & 0.535 \\
\hline
\end{tabular}

of its accumulation. Most often, organic sediment samples were taken from ditches characterized by slow water flow, or from stagnant water bodies with a low sedimentation rate of suspension and long-term adsorption of molybdenum. This is demonstrated by the lower molybdenum content (mean $1.1 \mathrm{mg} \cdot \mathrm{kg}-1$ ) in the river and stream sediments compared to the content in the sediments of stagnant water bodies, canals and ditches (mean 1.9$2.5 \mathrm{mg} \cdot \mathrm{kg}-1$ ) (Table 2).

The predominance of anthropogenic sources of molybdenum in the sediments is suggested by the analysis of its content according to the land use in the drainage basin area. Its lower content (geometric mean $<0.5 \mathrm{mg} \cdot \mathrm{kg}-1$ ) was found in the sediments of 
watercourses flowing across meadows and arable fields, while higher (geometric mean $1.1 \mathrm{mg} \cdot \mathrm{kg}-1$ ) was observed in lawns and urban parks (Table 2). Agricultural land is periodically subjected to anthropogenic impact, but most often it is of relatively low intensity. In contrast, parks and lawns are located in urban areas where pollutant emissions into the environment are much higher. In addition, it is common practice that parks are established in wasteland and post-industrial areas as part of their revitalization.

\subsection{Drainage basins of individual water courses}

In the drainage basins of individual rivers and streams, the molybdenum content in sediments is commonly variable (Table 2).

Bytomka River drainage basin. The high molybdenum content has been observed in the sediments of the Bytomka River (up to $12.0 \mathrm{mg} \cdot \mathrm{kg}-1)$. The most common content of molybdenum in its drainage basin is in the range of $1-2 \mathrm{mg} \cdot \mathrm{kg}-1$. Quite likely, the source of Mo was the Bobrek zinc smelter located (in the 19th century) in the upper reach of this river. In the close neighbourhood, a tailings heap of this smelter existed in the Bytomka River valley. In the lower reach of the river, another possible source of molybdenum is leachate from a tailings heap of the Zabrze Steelworks.

Czerniawka River drainage basin. High molybdenum accumulation (6.6-29.1 mg.kg-1) has been noted in sediments of watercourses and stagnant water bodies near the former Makoszowy coking plant and a spoil tip of the coal mine (in the lower course of Czerniawka River). The most likely origin of this metal in this area is particulates from long-term coal combustion in a coking plant active in the years 1908-2010 [30 lat..., 2010].

Kłodnica River drainage basin. In the upper Kłodnica River drainage basin, increased molybdenum content has been found in sediments of the stream draining the Kokociniec residential area in Katowice (1-2.5 mg.kg-1) and of an unnamed stream flowing from the Załęska Hałda residential area (2-7 mg.kg-1). In both cases, the presence of molybdenum can be attributed to the historical iron smelting. In the Kokociniec the processing of iron ore was conducted as early as 1650 , and the Ida iron smelter was active in this area in the 19th century [Degenhardt 1870, Złoty 2008]. For many years, the area of Załęska Hałda was a mining and metallurgical centre, where limonite iron ore was extracted from the Middle Ages onwards. Around 1640, hard coal mining started in this area. At the beginning of the 19th century, the Johanna zinc smelter was established in the Johanka settlement, and around 1843, the Victor zinc smelter was founded [Borowy 1997].

The highest molybdenum concentration (8.9-204.8 mg.kg-1) characterizes deposits of ditches surrounding the furnace waste dumps of the Halemba combined heat and power plant, located between the valleys of Żabnica and Jamna streams (Fig. 1). These ditches surround four no longer active settling ponds, which are reclaimed and afforested. In the sediments of stream transferring water from the ditches to the Kłodnica River, the molybdenum concentration is in the range of $7.5-20.9 \mathrm{mg} \cdot \mathrm{kg}-1$. Sediments of ditches around that landfill are abundant also in aluminium (0.80-2.20\%), and contain 19-49 mg.kg-1 of arsenic, 500$670 \mathrm{mg} \cdot \mathrm{kg}-1$ barium, $100-200 \mathrm{mg} \cdot \mathrm{kg}-1$ strontium, $50-80 \mathrm{mg} \cdot \mathrm{kg}-1$ copper, $300-740 \mathrm{mg} \cdot \mathrm{kg}-1$ vanadium, and several percent of iron [Pasieczna 2016c]. The source of arsenic, molybdenum and the other metals in the sediments is the leachate from the settling ponds. Enrichment of coal ash with molybdenum has been reported worldwide. The median content of molybdenum in the Grand Lake sediments near a fly ash storage facility (New Brunswick) is $5.6 \mathrm{mg} \cdot \mathrm{kg}-1$, with the geochemical regional background of $1.75 \mathrm{mg} \cdot \mathrm{kg}-1$ [Lalonde et al. 2011].

Potok Bielszowicki Stream drainage basin. The elevated molybdenum content in sediments of the Potok Bielszowicki Stream (up to $8.4 \mathrm{mg} \cdot \mathrm{kg}-1$ ) is probably associated with the activity of the currently closed down Batory steelworks located in the upper part of the drainage basin. It had been operated for over 100 years, and the environment has been polluted due to the storage of raw materials and industrial waste and sewage. Since 1873, the smelter under the name of Bismarckhütte produced steel pipes and sheets. In the period 1912-1915, missiles, ship boilers and armour plates were manufactured here. In the following years, the plant produced steel, metal sheets and mining machines. Redeployment of its production lines required the use of many raw materials. This influenced the composition of wastewater. The contaminants in the Potok Bielszowicki Stream sediments also originate from leachate of the Halemba-Wirek mine heap and industrial effluents from the mine.

Rawa River drainage basin. The molybdenum contamination of the Rawa River sediments (9.7-48.3 mg.kg-1) downstream of the Klimzowiec sewage treatment plant and the sediments of the Maroko reservoirs in its valley $(1.8-115.9 \mathrm{mg} \cdot \mathrm{kg}-1)$ can be attributed to the wastewater discharges from the Batory and Florian steelworks and the Silesia zinc smelter. Industrial wastewater discharges from these mills are also the likely reason for the concentration of molybdenum in sediments of stagnant water bodies in the area between the Florian and Pokój steelworks (Fig. 1). The molybdenum content here is in the range of $1.7-26.9 \mathrm{mg} \cdot \mathrm{kg}-1$.

A high molybdenum concentration $(200.0 \mathrm{mg} \cdot \mathrm{kg}-1)$ has been detected in a settling tank of the abandoned Batory Steelworks in Chorzów, located in the Rawa River valley. The source of molybdenum is wastewater discharged from the smelter to the tank over many years. Molybdenum belongs to the alloying elements in steel, and it was probably used in the products of the Batory Steelworks. Its content in structural steel rarely exceeds $0.4 \%$, but even its small amounts accumulated in the waste have caused the anomaly. The concentrations of chromium, vanadium and nickel in analysed sediments [Pasieczna 2016d] can be explained by the fact that molybdenum-doped steel also contains other metals.

Promna, Jamna, Ślepotka and Mleczna drainage basins. The lowest mean molybdenum content $(<0.5-0.6 \mathrm{mg} \cdot \mathrm{kg}-1)$ has been found in the drainage basins of these watercourses drain in the poorly urbanized southern part of the study area. A slight local increase in the content in sediments of Mleczna River (up to $5.1 \mathrm{mg} \cdot \mathrm{kg}-1)$ is most likely related to the accumulation of atmospheric particulates derived from fuel combustion.

Unnamed stream drainage basin. In Świętochłowice city, the molybdenum content in sediments of a series of small water bodies connected by stream without name has been found 
2-4 mg.kg-1. They have also been contaminated by silver, arsenic, lead and zinc. In this area, small zinc smelters were already active in the $19^{\text {th }}$ century. In 1823-1853, the Dawid, Constantin and Gabor zinc smelters were opened, and during the next decades the Guidotto zinc smelter was established [Piegza 2007]. The Konstancja zinc smelter (later renamed to Silesia) was built in 1847. The Klara zinc smelter, Zgoda (Eintracht) iron smelter, and some brickyards also became active at that time. In the 1930s, the Bethlen-Falwa (later Florian) iron smelters were established in the southern part of Świętochłowice. In Świętochłowice, there are also partially levelled small historical waste heaps of the Klara and Franciszek smelters [Brodziński et al. 2004]. Another mine heap in the northern part of the city is the so-called Ajska heap of mining waste from the Śląsk-Matylda coal mine and the industrial waste from the Silesia zinc smelter. The origin of molybdenum can be attributed to its presence in the processed $\mathrm{Zn}-\mathrm{Pb}$ ores from local mineral deposits. A similar origin is possible in case of increased molybdenum content (1.4-4.7 $\mathrm{mg} \cdot \mathrm{kg}-1)$ in sediments of the Żabie Doły reservoir complex, where zinc and lead ore tailings were deposited for many years [Cempiel et al. 2014, Nowak and Lutyńska 2015].

\subsection{Pollution sources}

Anomalous molybdenum concentrations in the sediments of the analysed area are first of all of anthropogenic nature and indicate significant environmental pollution. In some locations, they exceed the molybdenum content in the sediments of Poland many times, and even in the stream sediments of the Bieszczady Mountains, where there are geogenic anomalies associated with the occurrence of menilite shales [Bojakowska and Borucki 1994, Stojek 2013]. The maximum concentration is comparable with the levels found in the sediments from the areas of molybdenum mineralization and near the sites of extraction of molybdenum mineral deposits [Cook 2000, Yu et al. 2011].

The output data of PCA (Table 3) interpreted in accordance with the hypothetical sources of molybdenum indicate three components (F1, F2 and F3), which explain respectively $23.44 \%$, $11.80 \%$ and $9.27 \%$ of the variance. Factor $\mathrm{F} 1$, loadings $\mathrm{Cr}$, $\mathrm{Cu}$, $\mathrm{Fe}, \mathrm{Mo}, \mathrm{Ni}$ and $\mathrm{Sn}$, suggests that these elements are affected by industrial activities in addition to the natural content. These elements show a close relationship with Fe (Fig. 3) and indicate that the important source of molybdenum and other elements in this group is the iron and steel industry in the study area. The largest industrial consumption of molybdenum is associated with the production of special grades of steel and a variety of metallic alloys. It represents $65 \%$ of the general industrial use of this element [Jarrel et al. 1980]. Factor F2, loadings Ag, As, Cd, Pb and $\mathrm{Zn}$, suggests that these elements mainly come from $\mathrm{Zn}-\mathrm{Pb}$ ore mining, processing and zinc smelting. Factor $\mathrm{F} 3$, loadings $\mathrm{Al}$, $\mathrm{Ba}, \mathrm{Co}, \mathrm{Mn}$ and $\mathrm{Sr}$, points to the lithology of geological basement as the main source of elements.

Loading plot principal component F1 versus principal component F2 (Fig. 3) well illustrates the relationship of molybdenum to $\mathrm{Cr}$, $\mathrm{Cu}, \mathrm{Fe}, \mathrm{Ni}$ and partly $\mathrm{Sn}$, which mainly come from steel industry. Loading plot principal component F2 versus principal component

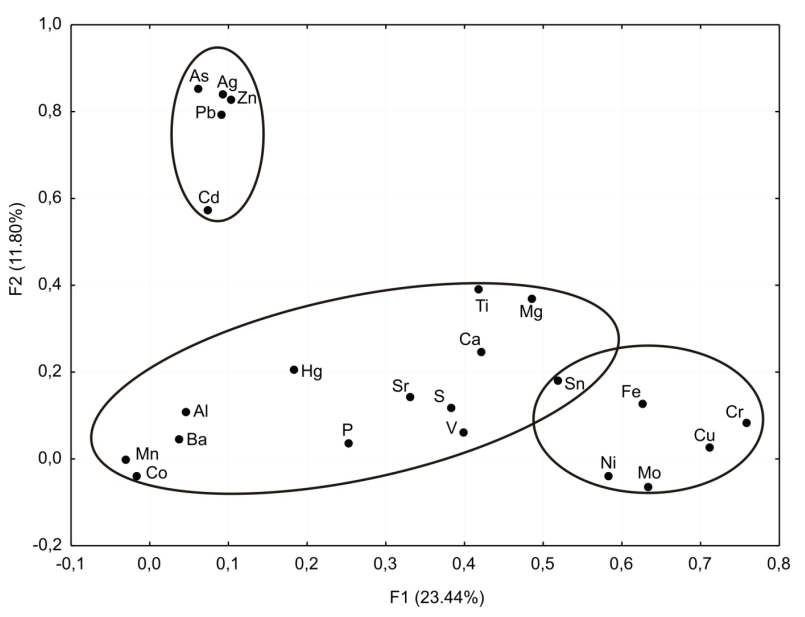

Figure 3. Loading plot from PCA. Principal component F1 versus principal component F2.

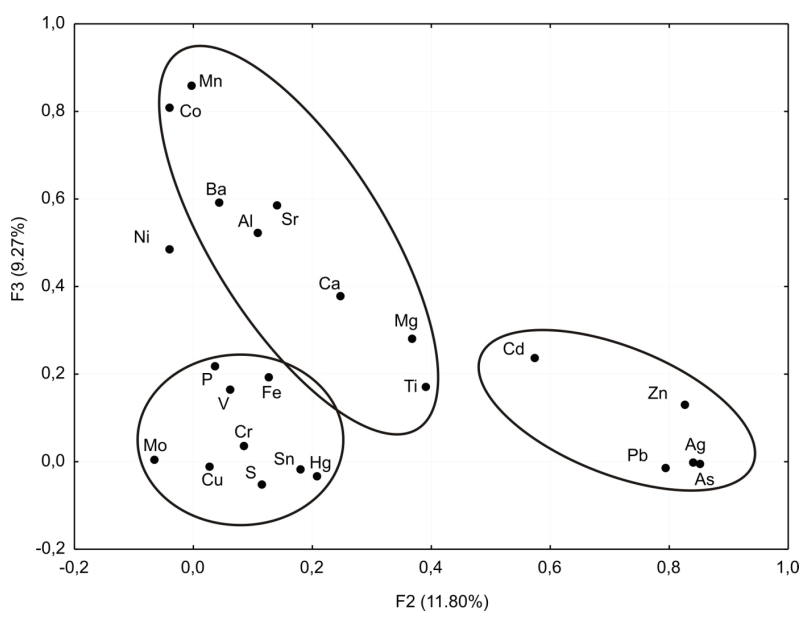

Figure 4. Loading plot from PCA. Principal component F2 versus principal component F3.

F3 (Fig. 4) where there is a clear relationship between Mo, S and $\mathrm{Hg}$ proves that molybdenum is introduced into the sediments in particulates due to hard coal combustion and the resulting storage of fly ash. The obvious proof of this reasoning is the high molybdenum content in sediments of ditches surrounding the abandoned storage site of the Halemba thermal power plant. Literature data prove that some ashes contain up to several tens of $\mathrm{mg} \cdot \mathrm{kg}-1$ of molybdenum [Bhattacharyya et al. 2009, Kalembkiewicz and Sočo 2009, Pandey et al. 2009; Deonarine et al. 2015]. Thus, even the reclaimed landfills of such ashes pose a threat to the quality of the environment due to the potential migration of trace elements, including molybdenum. Its mobile fractions, which can be leached from ash, account for $24 \%$ of the total content [Kalembkiewicz and Sočo 2009]. Moreover, a fraction of the molybdenum content may originate from phosphate fertilizers coming from agricultural land, what is highlighted in the form of its association with phosphorus (Fig. 4). Molybdenum content in phosphorites can reach $128 \mathrm{mg} \cdot \mathrm{kg}-1$ [Baturin 2002] and in commercial fertilizers reaches $4.4 \mathrm{mg} \cdot \mathrm{kg}-1$ [McBride and Spiers 2001]. 


\section{CONCLUSIONS}

In this study, the large number (1397) of fresh water sediment samples from the Upper Silesian Industrial Region was analysed and the content of molybdenum and 22 other elements was quantitatively determined. Relatively dense sampling sites along watercourses (about $250 \mathrm{~m}$ ) allowed detailed investigation of element distribution and distinguishing sources of pollution. To the best of our knowledge, this is the first work that shows detailed data on molybdenum content in the sediments from the central Upper Silesian Industrial Region. The goal of this work is to improve public knowledge and emphasize the problem of molybdenum pollution in the central Upper Silesia, which is the most industrialized and the most urbanized region in Poland. Our research reveals that in some areas of this region Mo occurs in relatively high amounts and can pose a threat to the human health and the quality of the environment due to the potential migration of elements. The major findings of the study are briefly summarised below.

1. The molybdenum content in analysed sediments is in the range of < 0.5-204.8 mg $\mathrm{kg}-1$; averaging $1.9 \mathrm{mg} \cdot \mathrm{kg}-1$. Almost half of the analysed samples (688) contain below $0.5 \mathrm{mg} \cdot \mathrm{kg}-1$ of molybdenum, and the amounts exceeding $5 \mathrm{mg} \cdot \mathrm{kg}-1$ are found only in $4.6 \%$ of samples.

2. We assume that the regional geochemical background level of molybdenum does not exceed $<0.5 \mathrm{mg} \cdot \mathrm{kg}-1$.

\section{REFERENCES AND LEGAL ACTS}

30 lat Kombinatu koksochemicznego "Zabrze” SA., 2010. Wydawnictwo Kombinat Koksochemiczny „Zabrze” SA.

ALARY J., BOURBON P., ESCLASSAN J., LEPERT, J.C., VANDAELE J., KLEIN F. 1983. Zinc, lead, molybdenum contamination in the vicinity of an electric steelworks and environmental response to pollution abatement by bag filter. Water, Air, and Soil Pollution $20: 137-145$.

AMORELLOD., ORECCHIOS. 2015. Vanadium and molybdenum concentrations in particulate from Palermo (Italy): analytical methods using voltammetry. Frontiers of Environmental Science \& Engineering 9: 605-614.

ARAKAKI T., MORSE J.W. 1993. Coprecipitation and adsorption of $\mathrm{Mn}$ (II) with mackinawite (FeS) under conditions similar to those found in anoxic sediments. Geochimica Cosmochimica Acta 57: 9-14.

BATURIN G.N 2002. Manganese and molybdenum in phosphorites from the ocean. Lithology and Mineral Resources 37: 412-428.

BATTOGTOKH B., LEE J.M., WOO N. 2014. Contamination of water and soil by the Erdenet cooper-molybdenum mine in Mongolia. Environmental Earth Sciences 71: 3363-3374.

BHATTACHARYYA S., DONAHOE R. J., PATEL D. 2009. Experimental study of chemical treatment of coal fly ash to reduce the mobility of priority trace elements. Fuel 88 : 1173 1184.

BOJAKOWSKA I., BORUCKI J., 1994. Molybdenum in stream sediment on the area of occurrence of the Dukla Folds and their margin. Geological Quarterly 38: 155-168.
3. In the southern part of the study area (Promna, Jamna, Jasienica and Ślepotka streams drainage basins), the sediments are characterized by low molybdenum content, which only locally exceed $0.5 \mathrm{mg} \cdot \mathrm{kg}-1$. Sediments of watercourses and stagnant water bodies in the industrial central and northern parts of the study (Kłodnica River, Rawa River, Potok Bielszowicki Stream and Bytomka River drainage basins) show significantly greater molybdenum concentrations.

4. The main source of molybdenum contamination in river and stream sediments of the study area is discharges of wastewater from steelworks and their waste heaps. This chemical element is also derived from wastes of mining and zinc ore metallurgy.

5. Another source of molybdenum is its emission into the atmosphere during coal combustion, and its migration from landfills of power plants.

6. The distribution of molybdenum in the sediments is variable, depending on the sediment type. It accumulates easily in organic sludge, while sandy sediments show the lowest ability to retain it.

7. Thesediments ofmeadowsandarablefieldsarecharacterized by significantly lower molybdenum concentrations than those in the urban and industrial areas.

BOROVEC Z., 1993. Partitioning of silver, beryllium and molybdenum among chemical fractions in the sediments from the Labe [Elbe] River in Central Bohemia, Czech Rep. GeoJournal 29, 359-364.

BOROWY R., 1997. Wczoraj - dziś - jutro... kopalni „KatowiceKloefas". Historia węglem pisana. Wydawnictwo KWK Katowice-Kloefas. Katowice.

BRODZIŃSKI I., GAŁKA M., WILK S., LIS J., PASIECZNA A., WOŁKOWICZ S.,STRZELECKI R., STRZEMIŃSKA K., KRIEGER W., 2004. Objaśnienia do Mapy Geośrodowiskowej Polski w skali 1:50 000, ark. Zabrze. Państw. Inst. Geol., Warszawa.

BURCHART-KAROL D. 2010. Środowiskowa ocena technologii hutnictwa żelaza i stali na podstawie LCA. Prace Naukowe GIG, Górnictwo i Środowisko 3: 5-13.

CEMPIEL E., CZAJKOWSKAA., NOWIŃSKA K., POZZI M. 2014. Przejawy antropopresji w zlewni rzeki Bytomki. Wydawnictwo Politechniki Śląskiej. Gliwice.

CHEN J., YUAN J., WU S., LIN B., YANG Z. 2012. Distribution of trace element contamination in sediments and riverine agricultural soils of the Zhongxin River, South China, and evaluation of local plants for biomonitoring. Journal of Environmental Monitoring 14: 2663-2672.

COOKS.J.2000. Distribution and dispersion of molybdenum in lake sediments adjacent to porphyry molybdenum mineralization, central British Columbia. Journal of Geochemical Exploration 71: $13-50$. 
CYGORIJNI K.J., 1989. Produkcja cynku z rud galmanowych w XIX wieku na ziemiach polskich.Wrocław-Warszawa-KrakówGdańsk-Łódź.

CZAJA S., 1999. Zmiany stosunków wodnych w warunkach silnej antropopresji (na przykładzie konurbacji katowickiej). Prace Naukowe Uniwersytetu Śląskiego, 1782.

DE GALE N., ADAMS C., WIXSON B., LOFTIN K., HUANG Y., 2004. Lead, zinc, copper, and cadmium in fish and sediments from the Big River and Flat River Creek of Missouri's Old Lead Belt. Environmental Geochemistry and Health 26: 37-49.

DE VOS W., TARVAINEN T. (eds.) 2006. Geochemical Atlas of Europe. Part 2. Geological Survey of Finland, Espoo.

DEGENHARDT O., 1870. Der Oberschlesian-PolnischeBergdistrict mit Hinweglassung des Diluviums. Karte von Oberschlesien 1:100 000. Verlag der Landkarten handlung von J.H. Neumann, Berlin.

DEONARINE A., KOLKER A., DOUGHTEN M.W. 2015. Trace elements in coal ash. USGS Fact Sheet: 2015-3037.

DUBININ A.V., USPENSKAYA T.Y., GAVRILENKO G.M., RASHIDOV V.A. 2008. Geochemistry and genesis of Fe$\mathrm{Mn}$ mineralization in island arcs in the West Pacific Ocean Geochemistry International 46: 1206-1227.

DWORAK J.S., 1995. Karol Godula pionier przemysłu cynkowego na Górnym Śląsku. Ruda Śląska.

ENZMANN R.D., 1972. Molybdenum: element and geochemistry. In: The Encyclopedia of Geochemistry and Environmental Sciences. Fairbridge ed., Van Nostrand Reinhold Co, New York: 753-759.

FU J., HU X., TAO X., YU H., ZHANG X. 2013. Risk and toxicity assessments of heavy metals in sediments and fishes from the Yangtze River and Taihu Lake, China. Chemosphere 93:1887-95.

GUCWA I., WIESER T., 1980. Geochemia i mineralogia skał osadowych fliszu karpackiego zasobnych w materię organiczną. Prace Mineralogiczne 69: 1-43.

HALMI M.I.E., AHMAD S.A., 2014. Chemistry, biochemistry, toxicity and pollution of molybdenum: A mini review. Journal of Biochemistry, Microbiology and Biotechnology 2:1-6.

JARREL W.M., PAGE A.L., ELSEEWI A.A. 1980. Molybdenum in the environment. Springer-Verlag New York.

KABATA-PENDIAS A., MUKHERJEE A., 2007. Trace Elements from Soil to Human. Springer-Verlag Berlin Heidelberg.

KABATA-PENDIAS A., PENDIAS H., 1999. Biogeochemia pierwiastków śladowych. Wydawnictwo Naukowe PWN Warszawa.

KALEMBKIEWICZ J., SOČO E., 2009. Lotny popiół przemysłowy jako potencjalne źródło emisji molibdenu. Ochrona Środowiska i Zasobów Naturalnych 40: 601-607.

KONDRACKI J., 2009. Geografia regionalna Polski. Wydawnictwo Naukowe PWN, Warszawa.

LALONDE B. A., ERNST W., COMEAU F., 2011. Trace metal concentrations in sediments and fish in the vicinity of ash lagoon discharges from coal-combustion plants in New Brunswick and Nova Scotia, Canada. Archives of Environmental Contamination and Toxicology 61: 472-481.

LI X., THORNTON I., 2001. Chemical partitioning of trace and major elements in soils contaminated by mining and smelting activities. Applied Geochemistry 16:1693-1706.
MACHOWSKI R., 2010. Przemiany geosystemów zbiorników wodnych powstałych w nieckach osiadania na Wyżynie Katowickiej. Prace Naukowe Uniwersytetu Śląskiego, 2811.

MAJ M., KALANDYK B., ZAPAŁA R., 2010. Nowoczesne metody recyklingu w przemyśle metalurgicznym. Archives of Foundry Engineering 10: 103-106.

McBRIDE M.B., SPIERS G. 2001. Trace element content of selected fertilizers and dairy manures as determined by ICPMS. Communications in Soil Science and Plant Analysis 32:139-156.

MENDEL R. R., BITTNER F., 2006. Cell biology of molybdenum. Biochimica Biophysica Acta 1763: 621-635.

MIGASZEWSKI Z.M., GAŁUSZKA A. 2003. Zarys Geochemii Środowiska. Wyd. Akademii Świętokrzyskiej, Kielce.

MIGASZEWSKI Z.M., GAŁUSZKA A. 2016. Geochemia Środowiska. Wyd. Naukowe PWN, Warszawa.

MOLENDAD., 1963. Górnictwo kruszcowe na terenie złóż śląskokrakowskich do połowy XVI wieku. Wyd. PAN, WrocławWarszawa-Kraków.

MOLENDA D., 1972. Kopalnie rud ołowiu na terenie złóż śląskokrakowskich w XVI-XVIII wieku. Wyd. Ossolineum, Wrocław.

MORSE J.W., ARAKAKI T., 1993. Adsorption and coprecipitation of divalent metals with mackinawite [FeS]. Geochimica et Cosmochimica Acta 57: 3635- 3640.

MUCHA D., 2010. Kanalizacja Rawy i otwartych kanałów ściekowych. Gospodarka Wodna 5: 209-215.

NIEMIEROWSKI W., 1983. Dwa wieki huty „Zabrze” 1782-1982. Zabrze.

NOCOŃ W., 2009. Metale ciężkie w osadach dennych wybranych dopływów rzeki Kłodnicy. Inżynieria Ochrony Środowiska 12: 65-76.

NOCOŃ W., KOSTECKI, M. 2005. Hydro-chemical characteristic of the Bytomka River. Archives of Environmental Protection 31: 31-42.

NOCOŃ W., KOSTECKI M., KOZŁOWSKI J., 2006. Charakterystyka hydrochemiczna rzeki Kłodnica. Ochrona Środowiska 28: 39-44.

NOWAK J., LUTYŃSKA S., 2015. Archiwum Gospodarki Odpadami i Ochrony Środowiska 17: 11-18.

PANDEY V.C., ABHILASH P.C., UPADHYAY R.N., TEWARI D.D. 2009. Application of fly ash on the growth performance and translocation of toxic heavy metals within Cajanus cajan L.: Implication for safe utilization of fly ash for agricultural production. Journal of Hazardous Materials 166: 255-259.

PASIECZNA A., BOJAKOWSKA I. 2016. Assessment of sediment pollution of anthropogenic water reservoirs in the central part of the Katowice Upland. Przegląd Geologiczny 10: 806-813.

PASIECZNA A. (ed.), FAJFER J., STRZEMIŃSKA K. $2016 a$. Detailed geochemical map of Upper Silesia 1: 25 000, Zabrze sheet. Polish Geological Institute, Warsaw.

PASIECZNA A. (ed.), FAJFER J., STRZEMIŃSKA K. 2016b. Detailed geochemical map of Upper Silesia 1: 25000 , Chorzów sheet. Polish Geological Institute, Warsaw.

PASIECZNAA. (ed.), FAJFER J., STRZEMIŃSKA K., TOMASSIMORAWIEC H. 2016c. Detailed geochemical map of Upper Silesia 1: 25 000, Ornontowice sheet. Polish Geological Institute, Warsaw. 
PASIECZNAA. (ed.), BOJAKOWSKA I., FAJFER J., NADŁONEK W., 2016d. Detailed geochemical map of Upper Silesia 1: 25 000, Mikołów sheet. Polish Geological Institute, Warsaw.

PATER Z., 2014. Podstawy metalurgii i odlewnictwa. Wyd. Politechniki Lubelskiej. Lublin.

PAULO, A., STRZELSKA-SMAKOWSKA, B., 2000. Rudy metal nieżelaznych i szlachetnych. Wydawnictwo AGH, Kraków.

PIEGZA M., 2007. Chropaczów - zarys dziejów osady, gminy, dzielnicy. Wyd. Muzeum Miejskiego w Świętochłowicach.

POULSON BRUCKER R.L., MCMANUS J., SEVERMANN S., BERELSON W.M. 2009. Molybdenum behavior during early diagenesis: Insights from Mo isotopes. Geochemistry Geophysis Geosystems 10: 1-25.

REIMANN C., DE CARITAT P., 1998. Chemical elements in the environment - Factsheets for the geochemist end environmental scientists. Springer, Berlin-Heidelberg.

SALMINEN R. (ed.), 2005. Geochemical Atlas of Europe. Part 1. Geological Survey of Finland. Espoo.

SCHWARZ G., MENDEL R.R., RIBBE M.W., 2009. Molybdenum cofactors, enzymes and pathways. Nature 460:839-849.

SJÖSTEDT S., WÄLLSTEDT T., GUSTAFSSON J.P., BORG H. 2009. Speciation of aluminium, arsenic and molybdenum in excessively limed lakes. Science of the Total Environment 407: 5119-5127.

SMEDLEY P.L., KINNIBURGH D.G. 2017. Molybdenum in natural waters: A review of occurrence, distributions and controls. Applied Geochemistry 84:387-432.

SORDOŃ-KULIBABA B., 2010. Program ochrony środowiska dla miasta Świętochłowice. Urząd Miasta Świętochłowice.

STOJEK M., 2013. The concentration of molybdenum and copper in rocks, soils and plants in the area of Jabłonki (Eastern Beskids Mts.). Ochrona Środowiska i Zasobów Naturalnych $24: 13-17$

SULIMIERSKI F., WALEWSKI W. (red.)1880-1914. Słownik geograficzny Królestwa Polskiego i innych krajów słowiańskich.
SZULC W., 2013. Transformacja polskiego hutnictwa żelaza do gospodarki wolnorynkowej. Wyd. Instytutu Metalurgii Żelaza, Gliwice.

SZUWARZYŃSKI M., 1996. Ore bodies in the Silesian-Cracow ore district, Poland. Prace Państwowego Instytutu Geologicznego 154: 9-24.

TANG Q., BAO Y., HE X., ZHOU H., CAO Z., GAO P. ZHONG Y., HU Y., ZHANG X. 2014. Sedimentation and associated trace metal enrichment in the riparian zone of the Three Gorges Reservoir, China. Science of the Total Environment 1: 258266.

VINK J., 2009. The origin of speciation: trace metal kinetics over natural water/sediment interfaces and the consequences for bioaccumulation. Environmental Pollution 157: 519-527.

VYSKOČILA., VIAU C. 1999. Assessment of molybdenum toxicity in humans. Journal of Applied Toxicology 19: 143-219

WYCZÓŁKOWSKI J., 1957. Szczegółowa Mapa Geologiczna Polski w skali 1:50 000, arkusz Zabrze. Instytut Geologiczny. Warszawa.

XIAO R., BAI J., HUANG L., ZHANG H., CUI B. LIU X. 2013. Distribution and pollution, toxicity and risk assessment of heavy metals in sediments from urban and rural rivers of the Pearl River delta in southern China. Ecotoxicology 22: 15641575.

YU CH., XU SH., CHEN G., ZHOU L. 2008. Leaching experiments on heavy metal Mo release from sharn molybdenum ore tailings. Ecology and Environment17: 636-640.

YU CH., XU SH., GANG M., CHEN G., ZHOU L. 2011. Molybdenum pollution and speciation in Nver River sediments impacted with Mo mining activities in western Liaoning, northeast China. International Journal of Environmental Research 5: 205-212.

ZŁOTYA., 2008. Ligota, Murcki i inne szkice historyczne. Bractwo Gospodarcze Związku Górnośląskiego, Katowice. 